\title{
Urocystis carcinodes discovered in Finland
}

\author{
TAUNO ULVINEN
}

\begin{abstract}
ULVINEN, T. 1980: Urocystis carcinodes discovered in Finland. - Karstenia 20: $16-18$.

Urocystis carcinodes (Berk. \& Curt.) Fisch. v. Waldh. was found on Actaea spicata L. in northern Finland. The taxonomy and distribution of the fungus are discussed. Without infection experiments it is hardly possible to decide whether the smut on Cimicifuga (U. carcinodes s. str.) and the smut on Actaea, referred to U. ferrarisiana (Ciferri) Zundel, are different species.
\end{abstract}

Tauno Ulvinen, Botanical Museum, University of Oulu, P.O. Box 191, SF-90101 Oulu 10, Finland

The smut fungi include many rare species. Several smuts are seldom collected and regarded as rare because their symptoms on host plants are very inconspicuous, but a large number of species are rarely seen in spite of having very large and conspicuous galls. One of these is Urocystis carcinodes (Berk. \& Curt.) Fisch. v. Waldh. (Tuburcinia carcinodes (Berk. \& Curt.) Liro) on Actaea and Cimicifuga species (Ranunculaceae). The first record for Finland was made by me in the province Perä-Pohjanmaa (Ostrobottnia borealis ultima), Rovaniemi rural commune, Jaatila, on 24.VII.1978 (specimen in OULU). The locality is on the eastern side of the River Kemijoki, by the brook Savioja on the SW slope of the hill Jaatilanvaara (or its western part Kelopuunvaara; Grid $27^{\circ} \mathrm{E}$ reference 73490:4267, alt. $90 \mathrm{~m}$ ).

I saw and collected only one swelling, which was 12 $\times 5 \mathrm{~mm}$ in size and located on the stalk of a lower leaflet of Actaea spicata L. (Fig. 1). However, the investigation was mainly directed towards the vascular plant flora and not all the individuals of $A$. spicata and $A$. erythrocarpa Fischer were checked for the smut.

The site is mixed grass-herb forest by the side of a little brook on a slope carrying mainly deciduous trees (Betula pubescens, Alnus incana, Prunus padus, Populus tremula) and a very dense stand of Matteuccia struthiopteris. In addition to the Actaea species, the flora of the site includes following vascular plants: Anthriscus sylvestris, Athyrium filixfemina, Circaea alpina, Crepis paludosa, Daphne mezereum, Elymus caninus, Equisetum pratense, Filipendula ulmaria, Geum rivale, Gymnocarpium dryopteris, Melica nutans, Milium effusum, Oxalis acetosella, Paris quadrifolia, Ribes nigrum, $R$. spicatum, and Thelypteris phegopteris. By the same brook, but further upstream, in stony grass-herb forest is the northernmost locality known for Cinna latifolia and the second northernmost known for Humulus lupulus. In addition, the following plants were noted in the vicinity: Convallaria majalis, Dryopteris filix-mas, Galium triflorum, Stellaria nemorum, and Viola selkirkii. Dr. Juha Suominen visited the site about two weeks erlier and found the northernmost occurence of Impatiens noli-tangere so far recorded in Finland. Actaea spicata is also growing near the northern limit of its Finnish distribution in this place. In brief, the brookside of Savioja is a very remarkable site.

Urocystis carcinodes was described from North America (U.S.A., Pennsylvania) on Cimicifuga racemosa (L.) Nutt. Earlier North American authors (e.g. Clinton 1902) included the smut on Actaea species in this species, too. Liro (1922) was the opinion that the smut on Actaea rubra (L.) Nutt. (cf. Sydow, Ustilagineen No 374) 'stimmt vorzüglich mit der typischen Tuburcinia carcinoides überein und dürfte zu dieser Art gehören'. However, Ciferri (1924) described the smut on Actaea as a species of its own, Tuburcinia ferrarisiana Ciferri, separating it mainly on the number of spores in the spore balls (usually $2-6$, very rarely 1 , whereas 1 -spored balls are numerous in $U$. carcinodes) and on the wall colour in peripheral sterile 


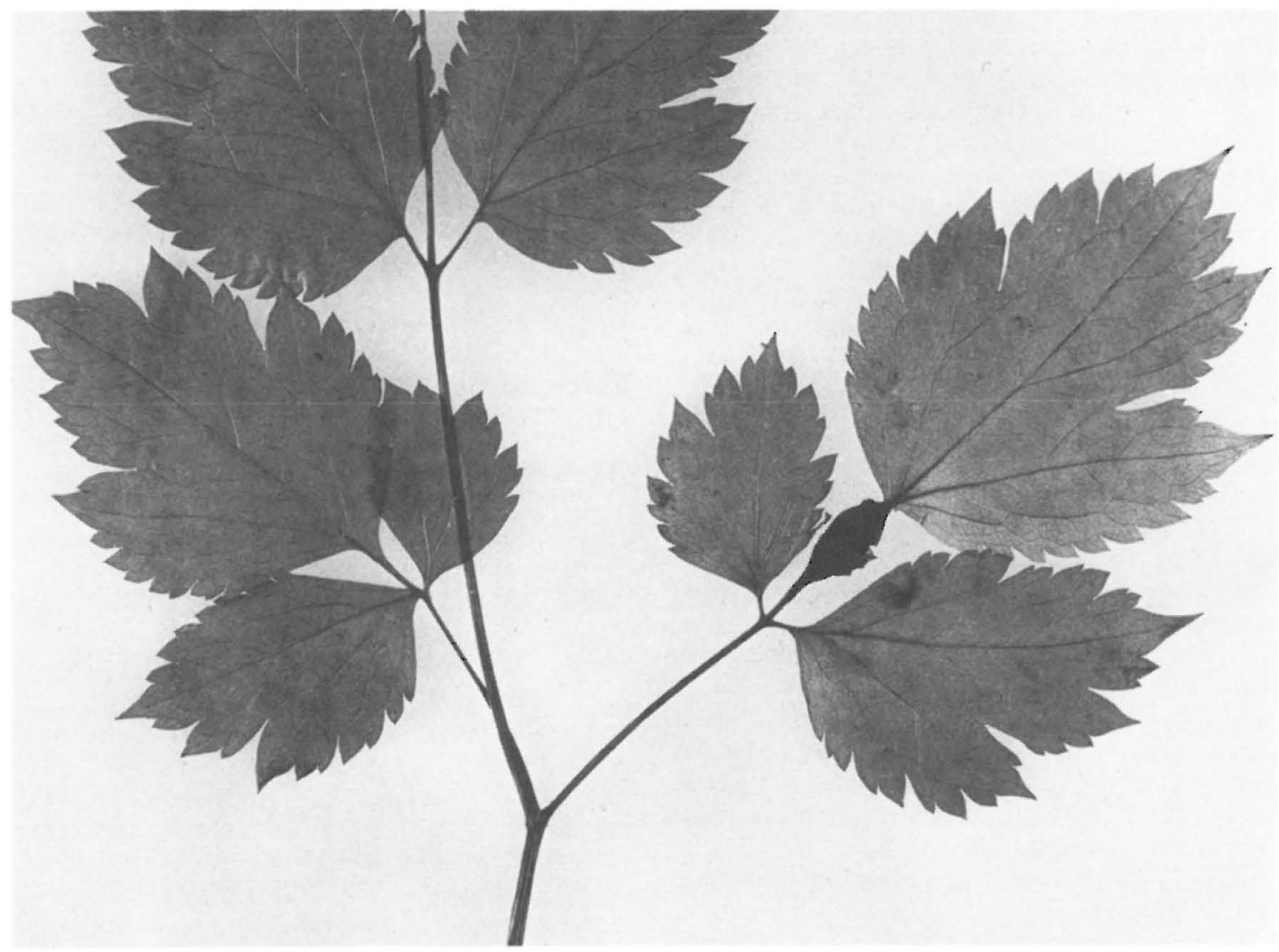

Fig. 1. Urocystis carcinodes on Actaea spicata collected in Finland, $\times 1$. - Photo Mauri Korhonen.

cells (yellowish brown, vs. more yellowish cells in $U$. carcinodes). Although these differences are small, $\mathrm{Ci}-$ ferri regards them as significant enough to distinguish the smut on Actaea from the smut on Cimicifuga, at least pro tempore.

When referring to Ciferri's Tuburcinia ferrarisiana, Liro (1938) remarks 'nur Keimungs- bzw. Infektionsversuche entscheiden können, ob die Pilze auf $A c$ taea und Cimicifuga artverschieden sind oder nicht'. Zundel (1953) keeps the species separate and makes the combination Urocystis ferrarisiana (Ciferri) Zundel, which is accepted by Uljanisčev (1968). On the other hand Lindeberg (1959), Index P.D.U.S. (1960), Conners (1967), and Kochman \& Majewski (1973) do not make this distinction.

As far as I know, no infecion experiments have been made, and when 'there is no oracle to be consulted for an infallible answer to the question: species or physiological race?' (Lindeberg 1959), the question must remain unanswered. Accordingly, mainly following Lindeberg (1959), I have used the collective name.

In the specimen collected at Rovaniemi the spore balls are $20-40(-50) \times 20-30(-35) \mu \mathrm{m}$, and each contain $1-7$ spores; 1 -spored balls are rare, though not 'rarissime'. The spores are $10-15 \mu \mathrm{m}$, somewhat angular, and dark brown; the sterile peripheral cells vary greatly in shape and size (about $3-15 \mu \mathrm{m}$ ), and mainly form a continuous layer; the wall colour in sterile cells is yellowish brown.

The specimen on Actaea rubra (Sydow, Ustilagineen No 374: U.S.A., Utah, Salt Lake Co, 1904 Carrett; H) closely resembles the Finnish specimen. Liro and Ciferri have studied the same material. The smut on Cimicifuga racemosa (Kellerman, Ohio Fungi Exs. No 79: U.S.A, Ohio, Fairfeld Co, 1902 Kellerman; H) possesses the features that Ciferri mentioned as distinctive: 1spored spore balls are fairly numerous, and the wall of the sterile cells is fairly pale and yellowish.

As already mentioned, the find at Rovaniemi is the first Finnish record of Urocystis carcinodes. On 
Actaea spicata it has been found only twice in the other Nordic countries, once in Norway (Hordaland: Eidfjord, Simodal, 1898 Selland; Jørstad 1943) and once in Sweden (Pite Lappmark: Arjeplog, Svartberget at Högheden, 1932 Wistrand; Lindeberg 1959). On Actaea erythrocarpa it has been seen in Sweden in Uppsala Botanic Garden, in the years 1939-41 causing smut galls on a plant which originated (brought in 1936) from Lule Lappmark (Lundell \& Nannfeldt, F. Exs. Suec. 856). Later on the plant was killed by the infection. 'In 1948, specimens of $A$. pachypoda Ell. (L. \& N., F. Exs. Suec. 2473b) and $A$. rubra (Ait.) Willd. f. neglecta (Gillm.) Robins. (=A. eburnea Rydb.) (L. \& N., F. Exs. Suec. 2473a) cultivated close by were found to have also become infected and died after a few years. In 1956 the smut appeared on $A$. pachypoda var. rubrocarpa (Killip) Fern.' (Lindeberg 1959).

Elsewhere in Europe the smut has been reported from only a few localities. The type locality of Tuburcinia ferrarisiana on Actaea spicata is in Italy (Piemonte, Valsesia). Zundel (1953) gives the type locality incorrectly ('Switzerland'). A find in Poland is reported by Kochman \& Majewski (1973), who also mention France. The fungus has not been collected in the U.S.S.R., although Uljaniščev (1968) considers its occurrence possible.

In North America the smut is somewhat commoner than in Europe. The following hosts have been mentioned: 'Actaea alba (L.) Mill.' (=? A. pachypoda var. rubrocarpa and $A$. rubra f. neglecta; see Fernald 1950: 671-672), A. arguta Nutt. (A. rubra subsp. arguta (Nutt.) Hultén), $A$. rubra (Ait.) Willd. and Cimicifuga racemosa (L.) Nutt. (Zundel 1953, Index P.D.U.S. 1960, Conners 1967). In addition Zundel (1953) reports the hosts Aconitum columbianum Nutt. and 'Atragene occidentalis
Hornem.' $(=$ ? Clematis pseudoalpina (Kuntze) Nelson in Index P.D.U.S. 1960) from the U.S.A., and Cimicifuga foetida $\mathrm{L}$. from India. Oddly enough, the Index P.D.U.S. (1960) does not give Cimicifuga racemosa in the list of hosts of Urocystis carcinodes.

Acknowledgement. Mr. Pentti Alanko, Head Gardener of the Botanic Garden, University of Helsinki, has kindly helped in checking literature.

\section{References}

Ciferri, R. 1924: Seconda contribuzione allo studio degli Ustilaginales (N. 23-47). - Atti Ist. Bot. Univ. Pavia 3(1): $77-97$.

Clinton, G.P. 1902: North American Ustilagineae. - J. Mycol. 8: 128-156.

Conners, I.L. 1967: An annotated index of plant diseases in Alaska, Canada and Greenland. - Canada Dept. Agric. Publ. 1251. 381 pp.

Fernald, M.L. 1950: Gray's manual of botany. 8th ed. 1632 pp. New York.

Index of plant diseases in the United States (Index P.D.U.S.) 1960. - U.S. Dept. Agric., Agic. Handb. 165. $531 \mathrm{pp}$.

Jørstad, I 1943: The ustilagineous genus Tuburcinia in Norway. - Nytt Mag. Naturvidensk. (B) 83: 231-246.

Kochman, J. \& Majewski, T. 1973: Grzyby (Mycota) 5. Podstawczaki (Basidiomycetes). Glowniowe (Ustilaginales). - 271 pp, 30 pls. Warszawa - Kraków.

Lindeberg, B. 1959: Ustilaginales of Sweden (exclusive of the Cintractias on Caricoideae). - Symb. Bot. Ups. 16(2): $1-175$.

Liro, J.I. 1922: Über die Gattung Tuburcinia Fries. - Ann. Univ. Fenn. Abo. (A) 1(1): 1-153.

-"- 1938: Die Ustilagineen Finnlands 2. - Ann. Acad. Sci. Fennicae (A)42(1): $1-720$.

Uḷjaniščev, V.I. 1968: Opredelitel' golovnevyh gribov SSSR. - $182 \mathrm{pp}$. Leningrad.

Zundel, G.L. 1953: The Ustilaginales of the world. Pennsylvania State Coll. Dept. Bot., Contrib. 176: $1-410$.

\footnotetext{
Accepted for publication

on| February 4, 1980
} 